\title{
Developing planning indicators for outdoor wind environments of high-rise residential buildings*
}

\author{
Xiao-yu $\mathrm{YING}^{\dagger 1}$, Grace $\mathrm{DING}^{2}$, Xiao-jun $\mathrm{HU}^{1}$, Yin-qi ZHANG ${ }^{3}$ \\ ( ${ }^{1}$ Department of Architecture, Zhejiang University City College, Hangzhou 310015, China) \\ $\left({ }^{2}\right.$ School of the Built Environment, University of Technology Sydney, Sydney NSW 2007, Australia) \\ ( ${ }^{3}$ Department of Building Innovation Technology, Shanghai Research Institute of Building Sciences (Group) Co., Ltd., Shanghai 310015, China) \\ †E-mail: yingxiaoyu@zucc.edu.cn
}

Received Jan. 20, 2016; Revision accepted Feb. 3, 2016; Crosschecked Apr. 7, 2016

\begin{abstract}
The construction of a building may change the microclimate in the vicinity, and planning indicators in a master plan may directly affect the outdoor physical environmental quality in residential areas. An inappropriate plan for a site may accelerate wind and intensify vortexes over places on the pedestrian levels, which leads to an adverse outdoor environment. Therefore, the design of a cluster of buildings should not focus only on the buildings but also provide a good outdoor environment around the buildings. To tackle the problem of inadequate wind environment, the relationship between the building's floor area ratio and height was identified in this study as the main planning indicator to be examined on its effects on the outdoor wind environment. A computational fluid dynamics (CFD) model was hence developed to simulate the wind conditions generated by some typical site layouts with different values for planning indicators under relevant weather conditions, which were typical of those in Hangzhou, China. The simulated wind conditions are assessed using the wind speed ratio over the whole area of the building cluster at the pedestrian level. The effects on the local wind condition due to the varying of the planning indicators are discussed whilst considering the potential construction costs. The indicators resulting in better external conditions are highlighted in the conclusion as the recommendation which could be used as a rule of thumb by architects and planners at the master planning stage. The study disproves the common belief in the practice that a lower floor area ratio means fewer buildings and therefore greater external comfort. In fact, the higher the building, the greater the outdoor comfort wind zone for pedestrians. However, the increment in comfort area is limited to buildings extending from 25 to 30 levels.
\end{abstract}

Key words: Outdoor wind environment, Planning indicators, Building cluster layout, High-rise building http://dx.doi.org/10.1631/jzus.A1600026

CLC number: TU241; TU98

\section{Introduction}

With rapid urbanization and continuous improvement of construction techniques, a variety of high-rise buildings with different layouts have emerged in large numbers and resulting environ-

\footnotetext{
* Project supported by the National Natural Science Foundation of China (No. 51308496), the Zhejiang Provincial Natural Science Foundation of China (No. LQ13E080003), and the Innovation Fund Projects for Study Abroad Returnees of Hangzhou (1st Batch, 2014), China

(D) ORCID: Xiao-yu YING, http://orcid.org/0000-0001-5317-255X

(C) Zhejiang University and Springer-Verlag Berlin Heidelberg 2016
}

mental problems of outdoor wind patterns have become increasingly prominent (He et al., 1997; Murakami, 1997; Yoshie et al., 2007). For example, high wind velocity in narrow channels between high-rise buildings and increased wind velocity can make pedestrians uncomfortable, disturb their outdoor activities or even expose them to potential risks, such as walking with difficulty and being blown over by the wind (Blocken et al., 2008). Alternatively, improper building layouts or building size may contribute to the formation of a dead air eddy zone between the buildings, a stagnant area with poor circulation (Ying et al., 2013). Therefore, it is necessary to explore how 
wind conditions are created to avoid adverse wind environments.

The main approaches to predict the wind environment around buildings are field measurements, wind tunnel tests, and numerical simulation (Stathopoulos and Baskaran, 1996; Chang and Meroney, 2003). At present, there are still some errors in predicting the subtle pressures of building surfaces using numerical simulation, but the overall wind environment has been simulated with high accuracy and practical value (Stathopoulos and Baskaran, 1996; Cochran and Irwin, 1999). Stathopoulos and Baskaran (1996) applied numerical simulation to a group of seven rectangular and parallel buildings and found that the resulting wind velocity distribution around the buildings was in good agreement with wind tunnel test results. Chang and Meroney (2003) applied Fluent (a computer software program) and four different $k-\varepsilon$ models (turbulent models) to calculate the vortex condition within a street canyon where high-rise residential buildings were arranged in parallel, analyzing the influence of the width-height ratio of the building. Stathopoulos (1997) studied the influence of variation in the height of buildings on wind velocity around the streets using a wind tunnel test. Hu and Wang (2005) used Phoenics (a computer software program) to carry out numerical simulation. The results showed that when a central building and the surrounding buildings were of equal height, the calculated and experimental values agreed with each other, while they differed if the heights were unequal. Taking the impact of different spacing into account, Li (2001) used Fluent to simulate three models based on existing high-rise buildings. In general, recent studies have focused on a single or simple layout of buildings and there has been no systematic analysis or assessment of the impact of a series of layout changes on the wind environment.

Oke and his colleagues, who have studied the relevant urban form and urban thermal environment, presented the effects of residential area patterns on outdoor air temperature (Oke, 1973). Arthur-Hartranft et al. (2003) pointed out that the pattern of significant land use would affect microclimate changes in a city. Further, Voogt and Oke (2003) identified the mechanism of impact of the outdoor landscape on urban climate. Atkinson (2003) discussed a computer model of heat island effects on urban areas of $20 \mathrm{~km}^{2}$.
Overall, research has focused on larger urban areas and has not considered thermal environment issues in smaller scale residential areas. This should be of great concern as residential areas constitute the major part of urban construction in a developing city.

On the other hand, Coceal et al. $(2006 ; 2007)$ investigated small building layouts, taking four homogeneous building cubes with a staggered layout, to develop a computer model (building density $\lambda=0.25$ ). The distribution of surrounding air and eddies was observed. Coceal et al. (2006) expanded the layout of the building cubes to staggered, aligned, and square arrays (Fig. 1), and compared the air flow for each layout. Claus et al. (2012) focused on a model where all buildings were of the same height. They recorded the differences in the airflow field when changing the initial wind direction in the model. Ying et al. (2013) analyzed the wind environment around a group of six square high-rise buildings. Their studies were confined to layouts with a fixed height and did not examine the relationship between a series of floor area ratios and building heights. However, designers such as architects need such studies during the planning stage of an actual design project.

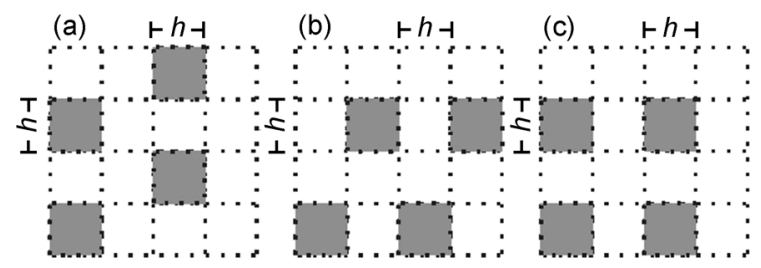

Fig. 1 Plan view of computational domains with staggered (a), aligned (b), and square (c) arrays of dimension $4 h \times 4 h \times 4 h$ ( $h$ is the cube height). Reprinted from (Coceal et al., 2006), Copyright 2006, with permission from Springer Science+Business Media

In this study, a computational fluid dynamics (CFD) model developed and validated by Ying et al. (2013) was used to study the influence of two planning indicators, namely the floor area ratio and building height, in the layout of a residential area on the wind environment. It was developed by Reynolds averaged equations and the renormalization group (RNG) $k-\varepsilon$ turbulence model (Ramechecandane and Gravdahl, 2012). By analyzing and comparing the wind speed ratios at the pedestrian level $(1.5 \mathrm{~m})$, the relationship between the wind environment condition 
and the layouts was obtained. This was then used to provide a reference and evaluation indicators for the layout of a residential area.

This study examined the influence of height variation and the distribution density of buildings on wind velocity around buildings using a computational simulation tool. By comparing the size of the area with a comfortable wind speed ratio, the study proposed developing indicators for outdoor wind environments to assist in planning high-rise residential buildings.

\section{Research method and simulation model}

The building density and floor area ratio are two major building capacity control indicators in a master plan. Planning and management departments control the development intensity and space usage comfort through developing these two indicators. This helps to avoid wasting land by building fewer houses, or reducing comfort because of high building density. The designers will follow the general process of a residential design project since they get the project task. The first step is to calculate the average residential building storeys by dividing the floor area ratio by building density. The height of the building is the average residential building storeys multiplied by the height of typical floor. Then the allowable maximum number of buildings in the site can be determined with the height of buildings. Following these indicators calculated, designers will seek reasonable building cluster layout and the number of the buildings in the site under the dual control of sunshine spacing analysis and fire spacing requirements through the "trial and error" method only.

\subsection{Definition of indicators}

The building density is a term used in master planning that refers to the construction coverage. The development density of a project is calculated by dividing the base area by the total site area in square meters. It reflects the extent of the land use and building density.

The floor area ratio is calculated by dividing the total floor area by the total site area. It will determine the proportion of the land price in the total housing cost for developers and is directly related to the living comfort of the occupants.
The building height refers to the height of the roof surface layer above the outdoor ground level.

The average residential building storey is the ratio of the total square footage of the residential building to the total base area, which reflects the characteristics of the space, form, and landscape of the residential area.

The fireproof distance is a requirement for fire fighting, security personnel evacuation, and reduction of fire thermal radiation between two adjacent buildings. In consideration of high-rise building fires, the planning and management department requires that the fireproof distance between two adjacent buildings should not be less than $13 \mathrm{~m}$ (MOHURD, 2005).

\subsection{Assessment method}

The research was designed to develop an assessment to assess the effect of the layout on the local wind conditions. The three indicators included in the model are the floor area ratio, building density, and building height. In a typical high-rise residential project in China, the floor area ratio is usually between 2.0 and 4.5. This is because when the floor area ratio is less than 2.0, multi-level buildings will dominate the site. However, if the floor area ratio is larger than 4.5 , the buildings would be higher than $100 \mathrm{~m}$ (30 floors), resulting in a substantial increase in construction cost. This is unusual for residential development in China. According to China's construction regulations, buildings with different floor numbers require different fire separation spacing and minimum sunlight intervals. Consequently, buildings with 11, 18,25 , and 30 floors are commonly accepted by designers and planners.

For simplicity and clarity, each layout is coded with the "floor area ratio-number of floors". For example, the layout 2.0-11 f represents a building with a floor area ratio of 2.0, with 11 floors (Table 1).

Table 1 Cases designed and simulated for comparison

\begin{tabular}{ccccc}
\hline \multirow{2}{*}{ Floor area ratio } & \multicolumn{4}{c}{ Code } \\
\cline { 2 - 5 } & $11 \mathrm{f}$ & $18 \mathrm{f}$ & $25 \mathrm{f}$ & $30 \mathrm{f}$ \\
\hline 2.0 & $2.0-11 \mathrm{f}$ & $2.0-18 \mathrm{f}$ & $2.0-25 \mathrm{f}$ & $2.0-30 \mathrm{f}$ \\
2.5 & & $2.5-18 \mathrm{f}$ & $2.5-25 \mathrm{f}$ & $2.5-30 \mathrm{f}$ \\
3.0 & & $3.0-18 \mathrm{f}$ & $3.0-25 \mathrm{f}$ & $3.0-30 \mathrm{f}$ \\
3.5 & & & $3.5-25 \mathrm{f}$ & $3.5-30 \mathrm{f}$ \\
4.0 & & & & $4.0-30 \mathrm{f}$ \\
\hline
\end{tabular}




\subsection{Layout model setting}

Using the indicators of floor area ratio and building density, architects calculate the building capacity and list the possible combinations of the project construction quantity and the height of the building (the average number of storeys). A preliminary design is then developed. A typical master plan involves setting buildings along the boundary of the site and developing a concentrated green space in the middle area. Another plan involves arranging the buildings in a uniform pattern and combining the entrance and high-rise buildings in favor of highly efficient land use. In this study, the layout of all the cases was designed following this principle.

Most high-rise buildings residential development projects in China have the same number of storeys and a similar load-bearing structure because variable building storeys would make the architectural design and main load-bearing structures more complex (Chao et al., 2010). Therefore, the simulation cases in this study had the same number of storeys.

Based on statistical data from the Planning Bureau of Hangzhou, China and by considering the effectiveness of the simulation results, the study assumed that the total site area in the model was about $100000 \mathrm{~m}^{2}$ (350 $\left.\times 290 \mathrm{~m}\right)$ (Fig. 2). The study did not consider inner streets which do not form part of a planning indicator. As streets will not affect the volume rate and building density, they are also not considered. The buildings were all point-type high-rise buildings and the typical floor area of each building was $1000 \mathrm{~m}^{2}$ (about $31.6 \mathrm{~m} \times 31.6 \mathrm{~m}$ ).

According to the planning regulations in Hangzhou, China, the distance between adjacent buildings must meet the fireproof requirements and should not be less than $13 \mathrm{~m}$ apart (MOHURD, 2005). Fig. 2 shows the possible layouts of the case study buildings with floor area ratios from 2.0 to 4.5 .

(a)

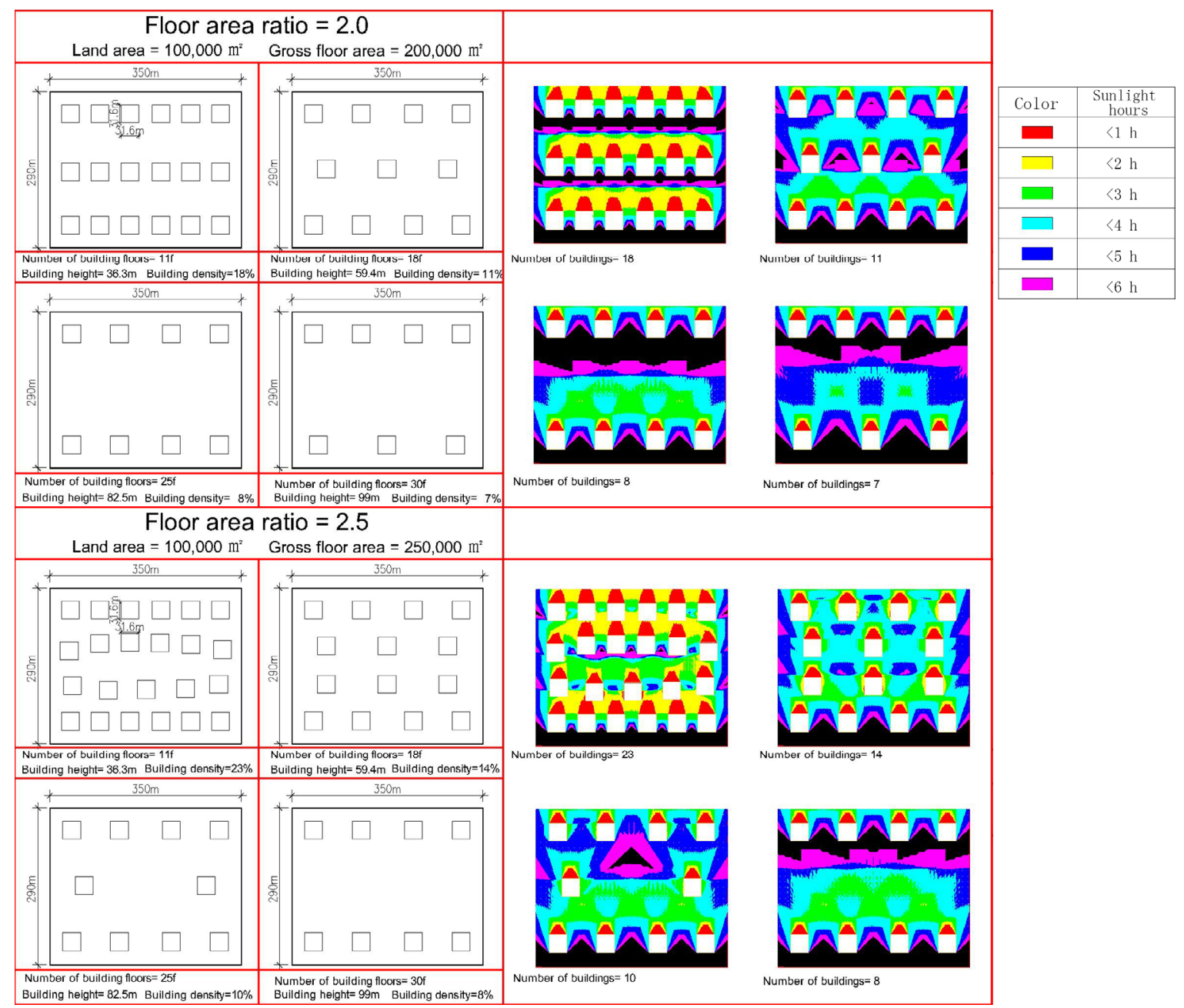


(c)

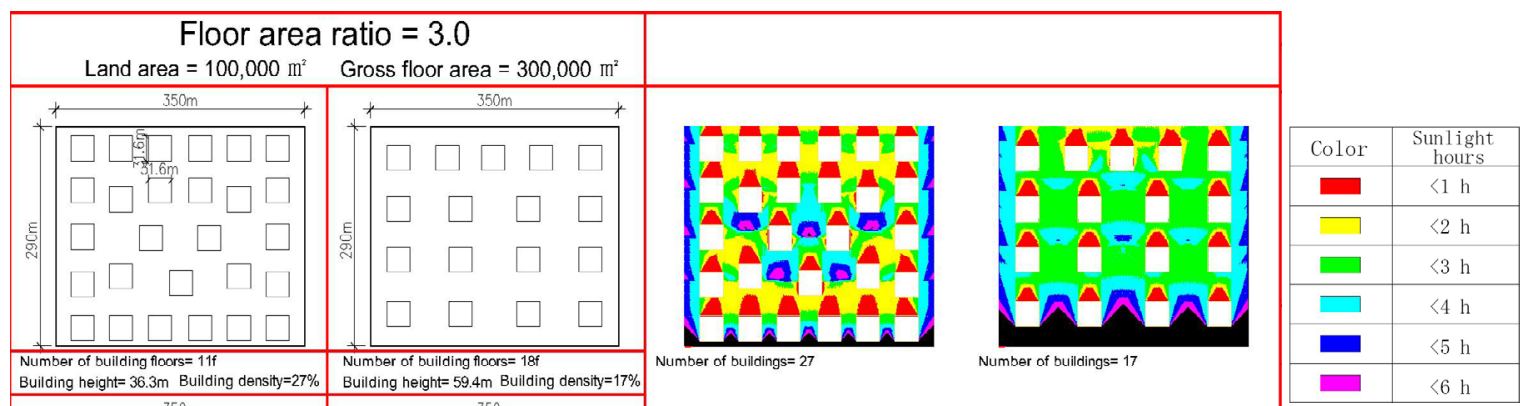

(d)
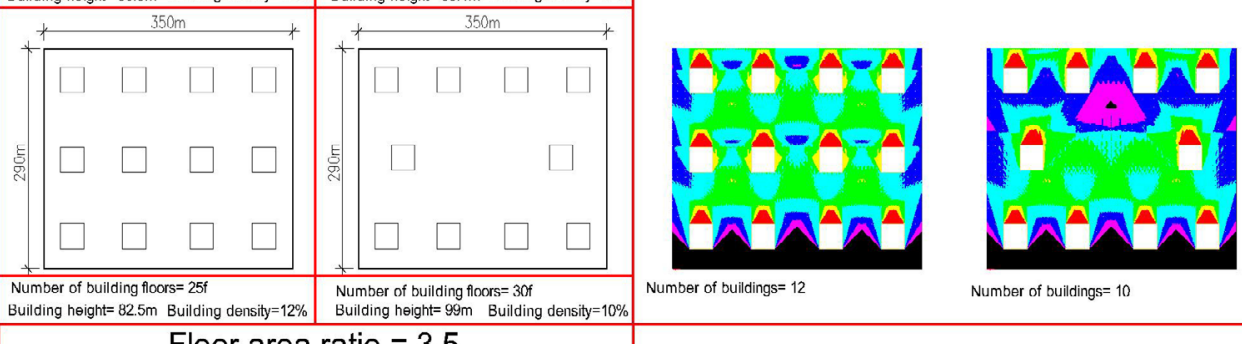

Number of bulldings $=10$

(d)

(e)
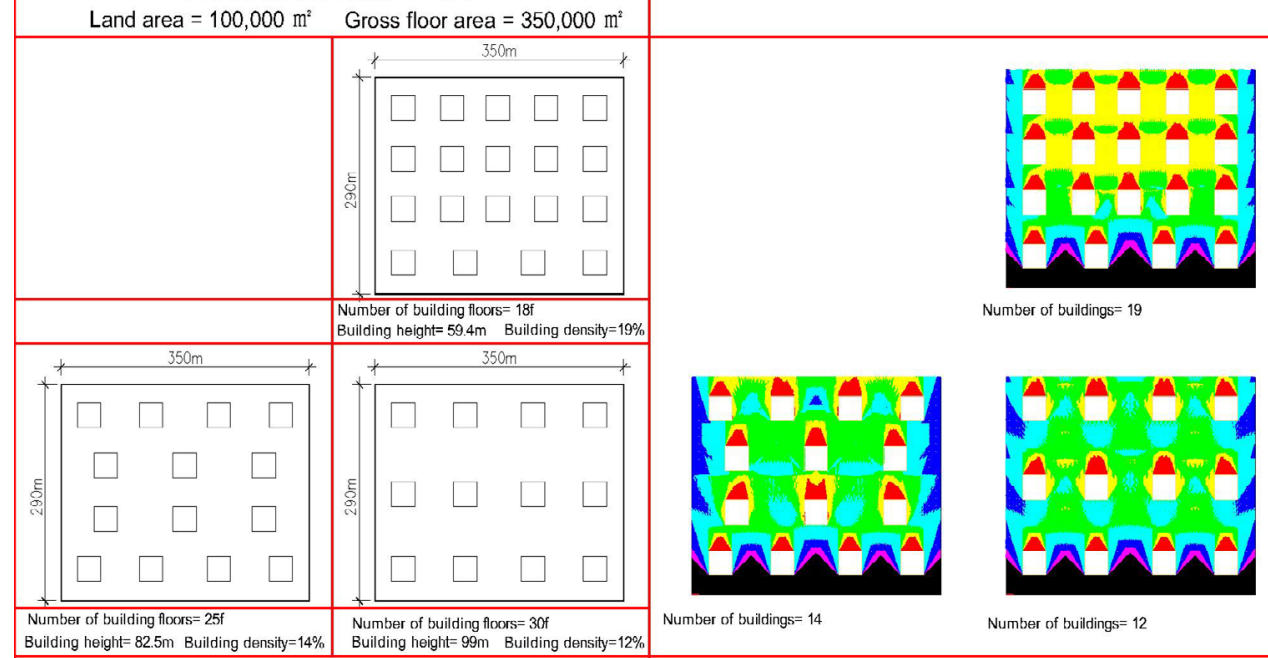

Number of buildings $=14$

Number of buildings= 12

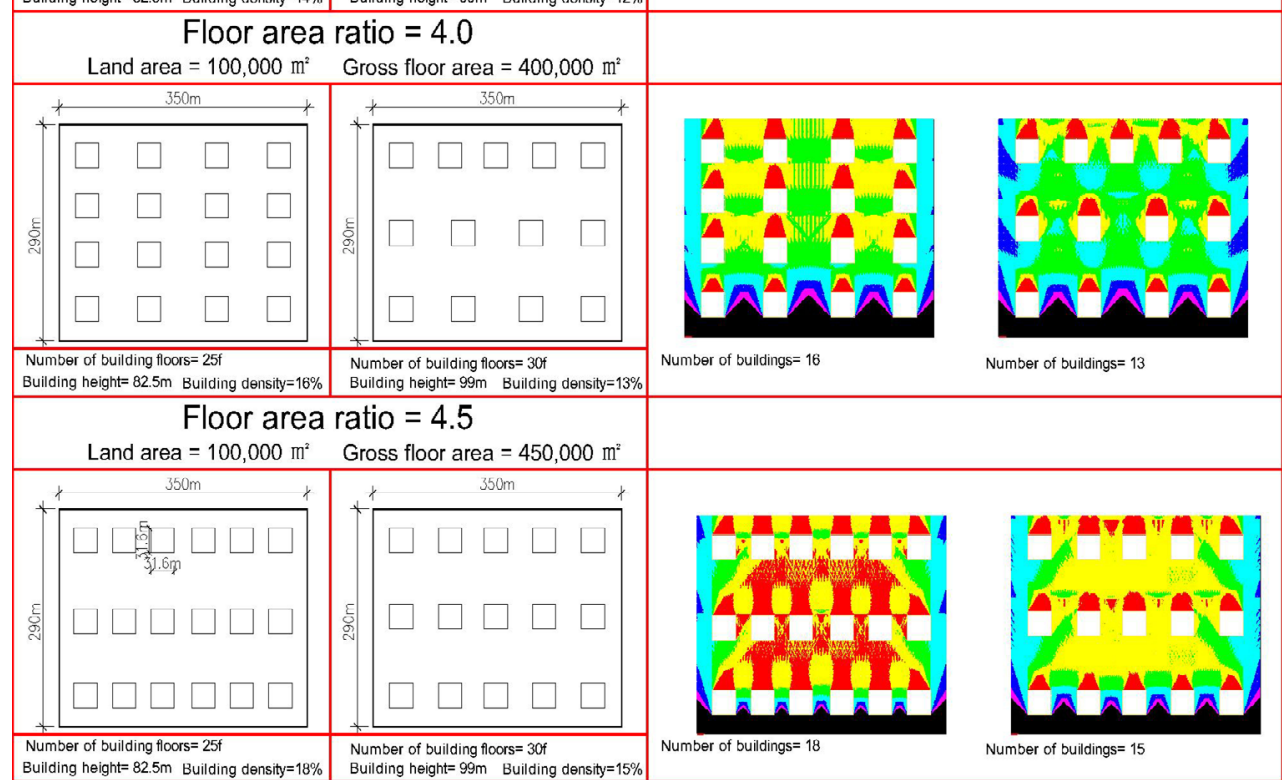

Fig. 2 Possible layout cases for floor area ratios from 2.0 to 4.5 and results of sunlight analysis (a)-(f) 
The planning and management department has developed an assessment of sunlight distance among buildings to avoid mutual occlusion of sunlight due to the high density and building height, and to allow some natural lighting of the indoor space (MOHURD, 2005). A sunlight analysis was conducted according to Tarch (a computer software program) to simulate the path of the sun. The results indicated that seven of the 20 layouts did not meet the sunlight standard of $2 \mathrm{~h}$ of full window sunshine during the day with the lowest annual elevation angle of the sun.

Consequently, after considering all these requirements, Table 2 summarizes 13 possible layouts with different floor area ratios.

Table 2 Thirteen possible layouts with floor area ratios from 2.0 to 4.0

\begin{tabular}{|c|c|c|c|c|c|c|}
\hline \multirow{2}{*}{$\begin{array}{c}\text { Floor } \\
\text { area } \\
\text { ratio }\end{array}$} & \multirow{2}{*}{$\begin{array}{c}\text { Gross } \\
\text { floor area } \\
\left(\mathrm{m}^{2}\right)\end{array}$} & \multirow{2}{*}{ Item } & \multicolumn{4}{|c|}{ Value } \\
\hline & & & $11 \mathrm{f}$ & $18 \mathrm{f}$ & $25 f$ & $30 \mathrm{f}$ \\
\hline \multirow{2}{*}{2.0} & \multirow{2}{*}{200000} & $\begin{array}{c}\text { Building } \\
\text { density }\end{array}$ & $18 \%$ & $11 \%$ & $8 \%$ & $7 \%$ \\
\hline & & $\begin{array}{c}\text { Number of } \\
\text { buildings }\end{array}$ & 18 & 11 & 8 & 7 \\
\hline \multirow{2}{*}{2.5} & \multirow{2}{*}{250000} & $\begin{array}{c}\text { Building } \\
\text { density }\end{array}$ & & $14 \%$ & $10 \%$ & $8 \%$ \\
\hline & & $\begin{array}{c}\text { Number of } \\
\text { buildings }\end{array}$ & & 14 & 10 & 8 \\
\hline \multirow{2}{*}{3.0} & \multirow{2}{*}{300000} & $\begin{array}{c}\text { Building } \\
\text { density }\end{array}$ & & $17 \%$ & $12 \%$ & $10 \%$ \\
\hline & & $\begin{array}{c}\text { Number of } \\
\text { buildings }\end{array}$ & & 17 & 12 & 10 \\
\hline \multirow{2}{*}{3.5} & \multirow{2}{*}{350000} & $\begin{array}{c}\text { Building } \\
\text { density }\end{array}$ & & & $14 \%$ & $12 \%$ \\
\hline & & $\begin{array}{l}\text { Number of } \\
\text { buildings }\end{array}$ & & & 14 & 12 \\
\hline \multirow{2}{*}{4.0} & \multirow{2}{*}{400000} & $\begin{array}{l}\text { Building } \\
\text { density }\end{array}$ & 36 & & & $13 \%$ \\
\hline & & $\begin{array}{l}\text { Number of } \\
\text { buildings }\end{array}$ & & & & 13 \\
\hline
\end{tabular}

A cell with a diagonal strikethrough means this layout does not meet the requirements of fire safety regulation distance or sunlight spacing. The 4.5 floor area ratio was deleted because it did not meet the requirements for any number of floors from 11 to 30

\subsection{Boundary conditions}

The approaching wind was created from a power-law model to approximate the mean velocity profile:

$$
U(z)=U_{\mathrm{G}}\left(z / z_{\mathrm{G}}\right)^{0.25} \text {. }
$$

The gradient height $z_{\mathrm{G}}$ was assumed to be $400 \mathrm{~m}$ and the mean wind velocity $U_{\mathrm{G}}$ at the gradient height was $13 \mathrm{~m} / \mathrm{s}$. Since the $k-\varepsilon$ model was used, the values of $k$ were required to account for the turbulence in the approaching wind. The turbulent kinetic energy $k$ can be calculated if the turbulence intensity at a given height is known. The turbulence intensity was set to $12 \%-13 \%$ at a height of $50 \mathrm{~m}$ above the ground, as suggested by $\mathrm{Hu}$ and Wang (2005).

The ground at the bottom of the computing domain was simulated by a rough wall, as it was assumed that the model buildings were mounted on a plate with roughness of 0.28 (Janour et al., 2005) in their wind tunnel test. The power-law wall function was applied to resolve the flow field near the walls and the building surfaces. The other boundary conditions, such as the outlet and the upper boundary, were not modified and thus the default settings were used. The boundary conditions applied in the computing domain are summarized in Table 3.

Table 3 Boundary conditions for the computing domain

\begin{tabular}{|c|c|}
\hline Position & Boundary condition \\
\hline Inlet & $\begin{aligned} U(z) & =U_{\mathrm{G}}\left(z / z_{\mathrm{G}}\right)^{0.25}, \quad U_{\mathrm{G}}=13 \mathrm{~m} / \mathrm{s}, \quad z_{\mathrm{G}}=400 \mathrm{~m} ; \\
k & =u_{*}^{2} /(C \mu)^{0.5}, C \mu=0.09 ; \varepsilon(z)=u_{*}^{3} /(\kappa z), \\
\kappa & =0.41\end{aligned}$ \\
\hline Outlet & Gauge pressure is 0 \\
\hline Bottom & $\begin{array}{l}\text { Wall, using the power-law wall function, the } \\
\text { roughness is } 0.28\end{array}$ \\
\hline Top & Free slip, flux normal to the boundary is zero \\
\hline Sides & $\begin{array}{l}\text { Free slip, flux normal to the boundary is zero; } \\
\text { symmetric boundary conditions is applied }\end{array}$ \\
\hline
\end{tabular}

\subsection{Domain size}

There are no explicit rules dictating the size of a computing domain. Many researchers determine their domain size by a trial-and-error approach because the domain size influences the computation results, as demonstrated by Baetke et al. (1990). Baskaran and Kashef (1996) suggested that the size of the domain can be a multiple of the characteristic height of the building and that the distance between any edge of the domain and the buildings must be at least five times the $H$ (characteristic height of the building). Following this suggestion, for this study the domain size was $13.8 H, 14.6 H$, and $5 H$ in the longitudinal $(x)$, lateral $(y)$, and vertical $(z)$ directions, respectively. 
This study follows research which compared CFD wind field modeling and field measurement data to study wind resources in a highly complex terrain (Jimenez et al., 2014). The comparison showed a good agreement between measured and modelled data that improved the simulation accuracy for long-term estimations. The validated model is modified and applied in this study.

\subsection{Evaluation criterion}

This study aimed to analyze the typical wind conditions around buildings in the east China monsoon region, where Hangzhou city is located. Although wind in the real environment is in an unstable state with velocity and direction, there is a wind direction in summer or winter which occurs much more frequently than other directions, ignoring the effect of the terrain. Therefore, this analysis was based on the direction of the prevailing winds.

When comparing wind speeds around different layouts in the actual environment, the situation is complicated due to the difference between the initial value of the wind inflow into the layouts in the boundary condition settings and the actual wind velocity. Therefore, the wind speed ratio was introduced so that the impact of the building layout on the wind environment could be assessed (Kubota et al., 2008; Kono et al., 2010). The wind speed ratio is the ratio of wind velocity (scalar velocity) at each point (height=1.5 m) to the wind velocity at the identical height at the inflow boundary. The wind speed ratio equation is

$$
R=\frac{V_{\mathrm{s}}}{V}
$$

where $R$ is the wind speed ratio, $V_{\mathrm{s}}$ is the velocity of a point, and $V$ is the inflow velocity.

The areas where the wind speed ratios are larger than 2.0 are recognized as strong wind flow areas. In these areas people would feel uncomfortable. On the other hand, the areas where the wind speed ratios are less than 0.5 are recognized as weak wind flow areas (Kubota et al., 2008; Kono et al., 2010). A comfortable wind speed ratio for all the year round is from 0.5 to 2.0, typically taken as about 1.85 (Kubota et al., 2008). This ratio is considered as the main criterion for judging different layouts.
The assessment also compared the cost of different master plan cases. This helps architects to make economical, practical, and acceptable designs for clients who are more concerned about the value of construction.

\section{Results and analysis}

After wind simulation, the wind speed distribution was plotted for all the 13 layouts. Fig. 3 shows the wind speed distribution of layout $2.0-11 \mathrm{f}$ as an example.

By masking areas with uncomfortable wind speed ratios, we could clearly identify the comfort zones of different layouts and make comparisons (Fig. 4).

Further, using the histogram plot tool in Photoshop CS (a graphic software program), the percentage of the area in the comfort zone can be calculated (Table 4).

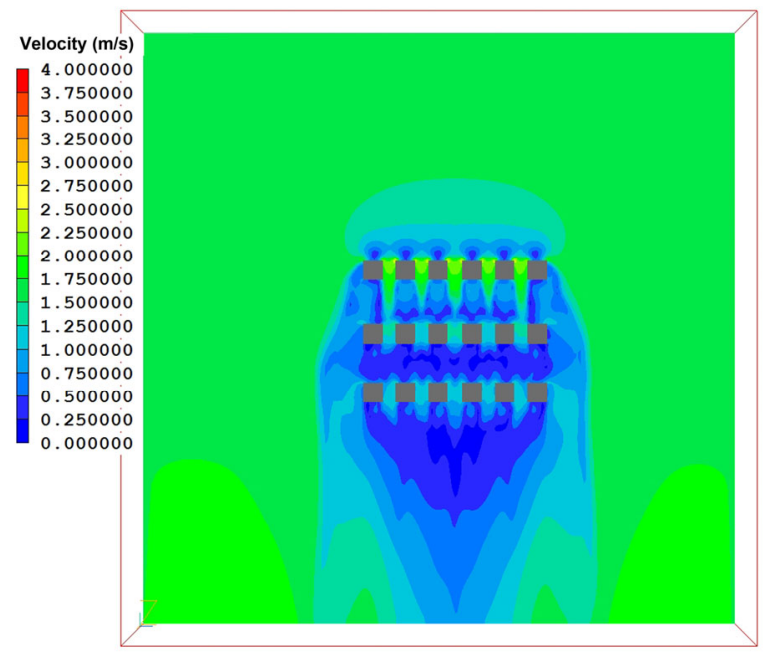

Fig. 3 Wind velocity distribution in a simulation result (layout 2.0-11f)

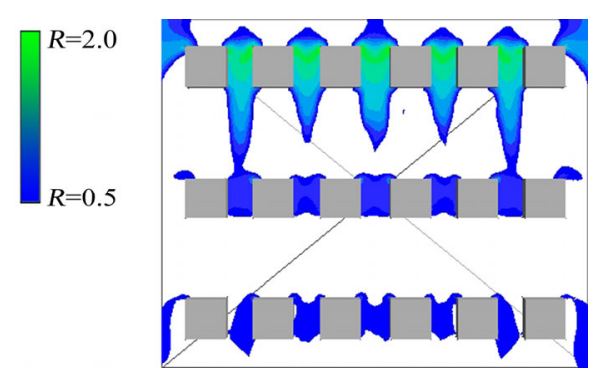

Fig. 4 Areas with a comfortable wind speed ratio between 0.5 and 2.0 (layout 2.0-11f) 


\subsection{Analysis of wind simulation results}

Due to the high density of buildings, the form of an $11 \mathrm{f}$ building layout could not meet the standard sunlight spacing. The simulation result revealed that under the 2.0-11f layout, the proportion of the area in the comfort zone was only about $43 \%$, which was the lowest among all the combinations. It was known that intensive building distribution would cause low wind speed. Therefore, if considering the external wind environment, $11 \mathrm{f}$ is not a suitable option for floor levels (Table 4).

During the stage of building layout planning, when the level reaches 18 , the lower floor area ratio would normally be associated with a higher comfort area ratio:
The comfort area ratio was $66 \%$ when the floor area ratio was $2.0,61 \%$ when the floor area ratio was 2.5 , and only $50 \%$ when the floor area ratio was raised to 3.0 .

For a residential site of development, it is unacceptable to have only half of the outdoor area considered to be within the comfort zone. Hence, during the planning stage of a residential site, if the floor area ratio is specified as 3.0, the architect should avoid the use of 18-level individual buildings in the design.

When the building level was greater than 25 , no significant difference was observed when the floor area ratio varied.

When the building level reached 30, the comfort area should rank from high to low: $3.0-30 \mathrm{f}=3.5-30 \mathrm{f}>$ 2.0-30f $>2.5-30 \mathrm{f}>4.0-30 \mathrm{f}$. Generally speaking, a lower

Table 4 Proportion of comfort zone in 13 possible layouts

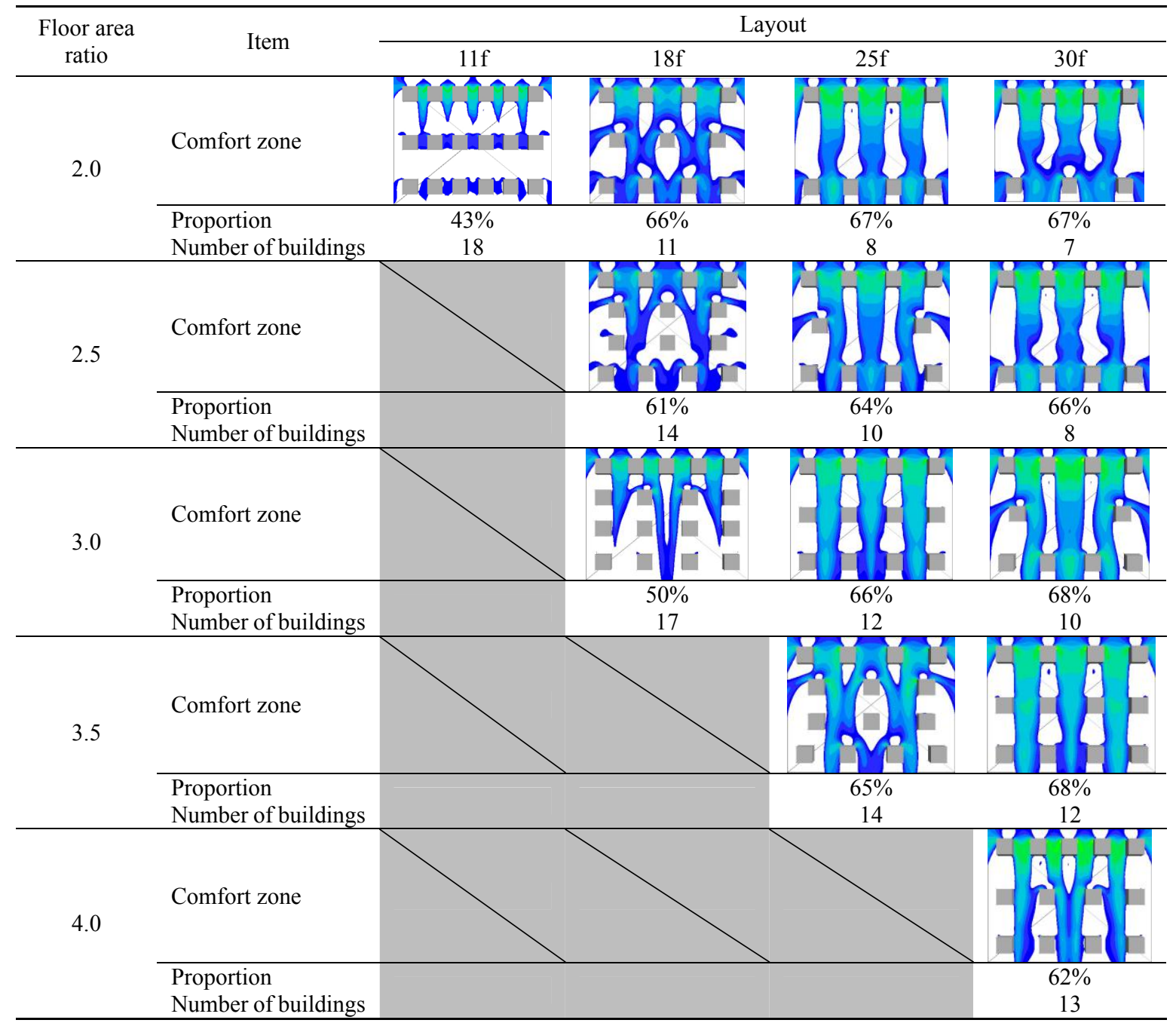

A cell with a diagonal strikethrough means this layout cannot meet the requirements of fire prevention or sunlight spacing 
floor area ratio means fewer buildings and greater external comfort areas. However, the simulation reflected different results.

\subsection{Comparison of construction costs due to the increasing number of floors}

From the analysis in Section 3.1, the increase in the number of building storeys did not bring significant improvement in the external wind environment.

Because of the requirements for elevators, wires, and civil water, introducing an additional level will increase the construction costs of a high-rise building. According to the statistics of construction cost of high-rise residential buildings in Hangzhou, the cost of completing a building unit of $11 \mathrm{f}$ to $18 \mathrm{f}$ was somewhere about $2750-2800 \mathrm{CNY} / \mathrm{m}^{2}$, and the cost for $25 \mathrm{f}$ to $30 \mathrm{f}$ was about $3450-3500 \mathrm{CNY} / \mathrm{m}^{2}$.

Fig. 5 indicates that the construction costs fell into two groups: one containing $11 \mathrm{f}$ and $18 \mathrm{f}$, and the other containing $25 \mathrm{f}$ and 30f. Comparing Fig. 6 with Fig. 5, it can be concluded that:

During the building layout planning, for the purpose of improving the outdoor wind environment, simply replacing the $11 \mathrm{f}-18 \mathrm{f}$ units with building units above level 25 may raise the comfort area size of the external wind environment by only $2 \%-5 \%$ (the floor area ratio would be $2.0,2.5$, or 3.0 ). However, the capital investment would increase dramatically, by $22 \%-24 \%$. Thus, this layout is not a cost-effective option.

Furthermore, the only layout option of 4.0-30f turned out to be a less suitable choice because of the low comfort area ratio and the high cost of construction.

Overall, if dealing with a layout with a floor area ratio of 2.0, any combination is viable except for a layout of 2.0-11f. When the ratio is 2.5 , the solution could be either a $2.5-18 \mathrm{f}$ or $2.5-25 \mathrm{f}$ layout. When the ratio is 3.0, a layout of $3.0-18 \mathrm{f}$ is a cost-effective choice while $3.0-25 \mathrm{f}$ are $3.0-30 \mathrm{f}$ layouts are also suitable if sufficient funds are provided. When the ratio is 3.5 , there is only a minor difference between layouts 3.5-25f and 3.5-30f. Hence, we recommend considering both options during planning. When the ratio is 4.0 , only one type of layout is suitable, namely 4.0-30f. This requires significant finance and the enhancement of the wind environment is only modest. Therefore, special designs should be considered, such as introducing a bottom overhead or body reverse effect to optimize the wind environment.

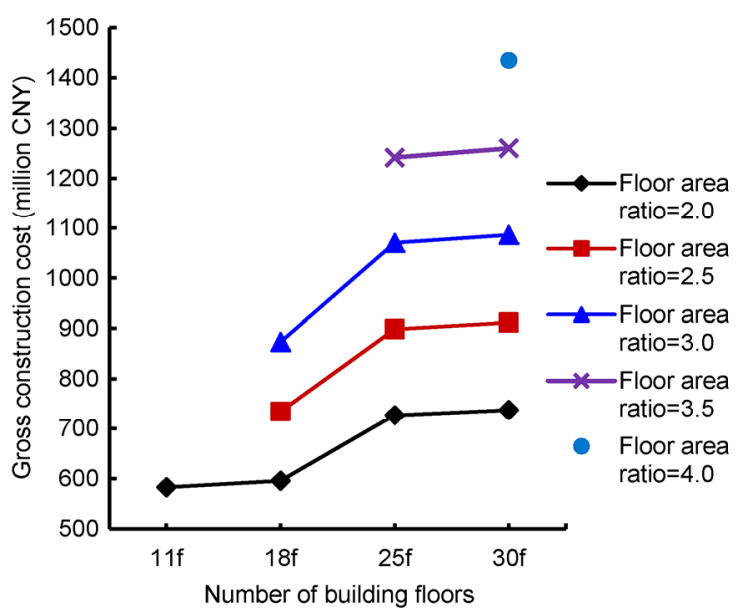

Fig. 5 Gross construction cost of each layout cost per square meter: $2750 \mathrm{CNY} / \mathrm{m}^{2}$ of $11 \mathrm{f} ; 2800 \mathrm{CNY} / \mathrm{m}^{2}$ of $18 f$; $3450 \mathrm{CNY} / \mathrm{m}^{2}$ of $25 f ; 3500 \mathrm{CNY} / \mathrm{m}^{2}$ of $30 \mathrm{C}(\mathrm{Cao}, 2014)$

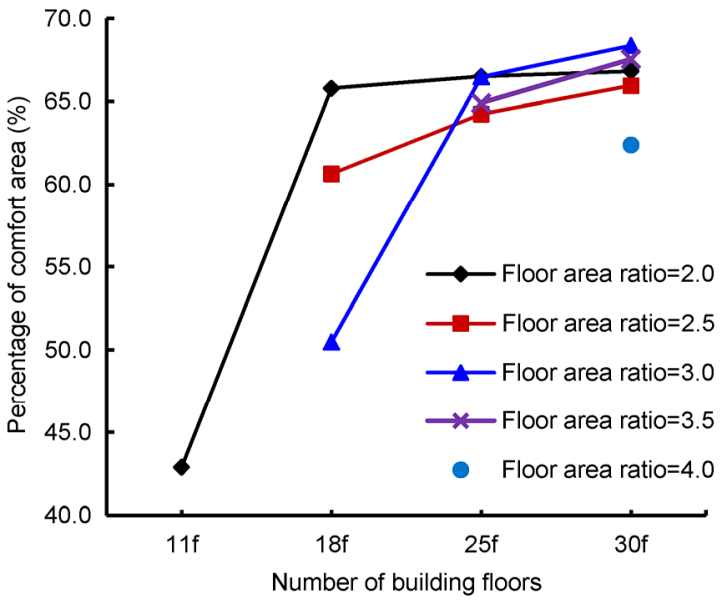

Fig. 6 Percentage of comfort area in each layout

\section{Conclusions}

This study considered the layout planning of 13 common types of high-rise building in Hangzhou, China with floor area ratios from 2.0 to 4.0.

Through simulations and comparisons of the outdoor wind environment and consideration of potential construction cost increments induced by raising building height, we draw the following conclusions as a reference for architects who wish to achieve a balanced state between the living space and the outdoor physical environment in their designs: 
1. With increasing numbers of storeys, the outdoor wind zone is more comfortable for pedestrians. However, the increase in the comfort area is limited when the number of floors increases from 25 to 30 .

2. In the case study of $2.0-11 \mathrm{f}$ with a building density of $18 \%$, the proportion of the area in the comfort zone was only $43 \%$. We do not recommend increasing the number of building units in this case because it will worsen the outdoor wind environment around the building. This result contradicts the traditional opinion that a lower floor area ratio means fewer buildings and greater external comfort areas.

3. The cases of 2.5-18f with a building density of $14 \%$ and $2.5-25 f$ with a building density of $10 \%$ could be given prime consideration when planning the layout of a cluster of buildings.

4. The case of 3.0-18f with a building density of $17 \%$ is an economical strategy for a master design. The cases of 3.0-25f (with a building density of $12 \%$ ) and 3.0-30f (with a building density of $10 \%$ ) could be considered if the project is adequately financed.

5. There was not much difference between the cases of 3.5-25f (with a building density of $14 \%$ ) and 3.5-30f (with a building density of $12 \%$ ). Thus, both are recommended.

6. In the case with a floor area ratio of 4.0 , only a cluster of 30-storey buildings met the sunlight requirement. Moreover, special design features should be considered, such as a bottom overhead or a twisted building shape, to improve the outdoor wind environment around the buildings.

One limitation of this study is that the assessment did not take account of the buildings around the site which can greatly influence the wind environment and external comfort. In particular, the number of storeys in these buildings may be a major factor affecting the external environment. In addition, the plans of all the buildings were square in this study. However, in practice there are various plan forms. Different kinds of plans and building shapes would also be influencing factors. In future study, the method proposed in this study should find an application to a real plan and show how it can help in decision-making.

\section{References}

Arthur-Hartranft, S.T., Carlson, T.N., Clarke, K.C., 2003. Satellite and ground-based microclimate and hydrologic analyses coupled with a regional urban growth model.
Remote Sensing of Environment, 86(3):385-400. http://dx.doi.org/10.1016/S0034-4257(03)00080-4

Atkinson, B.W., 2003. Numerical modeling of urban heatisland intensity. Boundary-Layer Meteorology, 109(3): 285-310. http://dx.doi.org/10.1023/A:1025820326672

Baetke, F., Werner, H., Wengle, H., 1990. Numerical simulation of turbulent flow over surface-mounted obstacles with sharpedges and corners. Journal of Wind Engineering and Industrial Aerodynamics, 35:129-147. http://dx.doi.org/10.1016/0167-6105(90)90213-V

Baskaran, A., Kashef, A., 1996. Investigation of airflow around buildings using computational fluid dynamics. Engineering Structures, 18(11):861-875. http://dx.doi.org/10.1016/0141-0296(95)00154-9

Blocken, B., Stathopoulos, T., Carmeliet, J., 2008. Wind environmental conditions in passages between two long narrow perpendicular buildings. Journal of Aerospace Engineering, 21(4):280-287.

http://dx.doi.org/10.1061/(asce)0893-1321(2008)21:4(280)

Cao, Q.S., 2014. Technical economy problems of high-level buildings. Zhejiang Construction Cost, 28(3):58-63 (in Chinese).

Chang, C.H., Meroney, R.N., 2003. Concentration and flow distributions in urban street canyons: wind-tunnel and computational data. Journal of Wind Engineering and Industrial Aerodynamics, 91(9):1141-1154. http://dx.doi.org/10.1016/S0167-6105(03)00056-4

Chao, Y.K., Zhang, F., Teng, S.H., 2010. Practical Building Design Manual. China Architecture \& Building Press, Beijing, China (in Chinese).

Claus, J., Coceal, O., Thomas, T.G., et al., 2012. Winddirection effects on urban-type flows. Boundary-Layer Meteorology, 142(2):265-287. http://dx.doi.org/10.1007/s10546-011-9667-4

Coceal, O., Thomas, T.G., Belcher, E., 2006. Mean flow and turbulence statistics over groups of urban-like cubical obstacles. Boundary-Layer Meteorology, 121(3):491-519. http://dx.doi.org/10.1007/s10546-006-9076-2

Coceal, O., Thomas, T.G., Castro, I.P., et al., 2007. Spatial variability of flow statistics within regular building arrays. Boundary-Layer Meteorology, 125(3):537-552. http://dx.doi.org/10.1007/s10546-007-9206-5

Cochran, L., Irwin, P., 1999. Microclimate design features for buildings and landscaping. New Orleans Structures Congress, New Orleans, USA, p.1051-1054.

He, P., Katayama, T., Hayashi, T., et al., 1997. Numerical simulation of air flow in a urban area with regularly aligned blocks. Journal of Wind Engineering and Industrial Aerodynamics, 67-68:281-291. http://dx.doi.org/10.1016/S0167-6105(97)00079-2

Hu, C.H., Wang, F., 2005. Using a CFD approach for the study of street-level winds in a built-up area. Building and Environment, 40(5):617-631. http://dx.doi.org/10.1016/j.buildenv.2004.08.016 
Janour, Z., Bezpalcova, K., Sedenkova, H., 2005. Wind tunnel simulations of flow and dispersion over urban area. 4th European and African Conference on Wind Engineering, Prague, Czech. Czech Society for Mechanics, Czech, p.152-153.

Jimenez, B., Rimpl, D., Moennich, K., 2014. Validation and comparison of wind resource models in highly complex terrain. European Wind Energy Association Conference and Exhibition, Barcelona, Spain, p.423-428.

Kono, T., Tamura, T., Ashie, Y., 2010. Numerical investigations of mean winds within canopies of regularly arrayed cubical buildings under neutral stability conditions. Boundary-Layer Meteorology, 134(1):131-155. http://dx.doi.org/10.1007/s10546-009-9434-y

Kubota, T., Miura, M., Tominaga, Y., et al., 2008. Wind tunnel tests on the relationship between building density and pedestrian-level wind velocity: development of guidelines for realizing acceptable wind environment in residential neighborhoods. Building and Environment, 43(10): 1699-1708. http://dx.doi.org/10.1016/j.buildenv.2007.10.015

Li, Z., 2001. Numerical analysis of the wind field on high buildings. Journal of Xi'an Jiaotong University, 35(5): 471-474 (in Chinese).

MOHURD (Ministry of Housing and Urban-Rural Development of the People's Republic of China), 2005. Code for Design of Civil Buildings, GB 50352-2005. MOHURD, Beijing, China (in Chinese).

Murakami, S., 1997. Current status and future trends in computational wind engineering. Journal of Wind Engineering and Industrial Aerodynamics, 67-68:3-34. http://dx.doi.org/10.1016/S0167-6105(97)00230-4

Oke, T.R., 1973. City size and the urban heat island. Atmospheric Environment (1967), 7(8):769-779. http://dx.doi.org/10.1016/0004-6981(73)90140-6

Ramechecandane, S., Gravdahl, A.R., 2012. Numerical investigations on wind flow over complex terrain. Wind Engineering, 36(3):273-296. http://dx.doi.org/10.1260/0309-524X.36.3.273

Stathopoulos, T., 1997. Computational wind engineering: past achievements and future challenges. Journal of Wind Engineering and Industrial Aerodynamics, 67-68:509-532. http://dx.doi.org/10.1016/S0167-6105(97)00097-4

Stathopoulos, T., Baskaran, A., 1996. Computer simulation of wind environment conditions around buildings. Engineering Structures, 18(11):876-885. http://dx.doi.org/10.1016/0141-0296(95)00155-7

Voogt, J.A., Oke, T.R., 2003. Thermal remote sensing of urban climates. Remote Sensing of Environment, 86(3):370-384. http://dx.doi.org/10.1016/S0034-4257(03)00079-8

Ying, X.Y., Zhu, W., Hokao, K., et al., 2013. Numerical re- search of layout effect on wind environment around high-rise buildings. Architectural Science Review, 56(4): 72-278. http://dx.doi.org/10.1080/00038628.2012.708165

Yoshie, R., Mochida, A., Tominaga, Y., et al., 2007. Cooperative project for CFD prediction of pedestrian wind environment in the Architectural Institute of Japan. Journal of Wind Engineering and Industrial Aerodynamics, 95(9-11):1551-1578.

http://dx.doi.org/10.1016/j.jweia.2007.02.023

\section{中文概要}

题 目: 室外风环境视角下的高层住宅项目规划指标研究

目 的: 确定建筑容积率、建筑密度和建筑层数之间的关 系, 并将其作为主要的规划指标, 研究其对室外 风环境的影响。

创新点: 在以高层、高密度为特点的城市建设中, 一个地 块的用地规划指标可直接影响居住区的室外物 理环境质量。一个高层建筑群的规划设计不应该 只关注建筑物, 还应考虑室外物理环境的品质。 本研究从室外风环境角度出发, 对 13 种 “容积 率-建筑密度-建筑层数” 指标组合形成的高层建 筑群布局进行对比, 从而得到可直接服务于城市 建设项目的规划策略。

方 法: 1. 通过确定建筑容积率、建筑密度和建筑层数之 间的关系, 建立三维高层建筑群布局模型, 列出 19 种可能的指标组合 (图 2); 2. 通过日照模拟 分析工具 Tarch 和建筑消防间距计算笁选出 13 种 符合当前规划要求的指标组合; 3. 运用风环境模 拟软件 Phoenics, 对 13 种指标组合形成的高层建 筑群布局进行风环境模拟运算; 利用图形分析软 件 Photoshop CS, 计算出舒适风面积比值, 并进 行相互对比 (图 3 和 4); 4. 根据土建造价对不同 建筑群布局的总造价进行对比（图 6)。

结 论: 在规划设计中, 通常认为较低的容积率和较低的 建筑高度意味着建筑体量较小, 室外物理环境会 更好。但是, 本研究发现建筑层数越多、建筑高 度越高, 行人高度的室外舒适风区面积越大。不 过, 建筑层数从 25 层升到 30 层, 舒适风区面积 增加有限。加之考虑层数越高导致造价越高的因 素, 当面对容积率为 2.0 4.0 的高层地块时, 不 能简单地认为建筑层数最高的规划方案就是最 好的方案。

关键词: 室外风环境; 规划指标; 建筑群布局; 高层建筑 